\title{
Deoxyribonucleic Acid Base Composition of Serotype Strains of Staphylococcus aureus
}

\author{
By J. BOHÁČEK, M. KOCUR AND T. MARTINEC \\ Institute of Biophysics, Czechoslovak Academy of Sciences, Brno, and Czechoslovak \\ Collection of Micro-organisms, University J. E. Purkyně, Brno, Czechoslovakia
}

(Accepted for publication 2 July $\mathrm{I} 97 \mathrm{I}$ )

SUMMARY

The percentage guanine + cytosine (GC) content of the DNA of I9 serotype strains of Staphylococcus aureus determined from melting temperatures $\left(T_{\mathrm{m}}\right)$ and the $E_{260} / E_{280}$ ratio at $\mathrm{pH} 3$ ranged from 30.2 to $35 \% \mathrm{GC}$, average $32.5 \% \mathrm{GC}$.

\section{INTRODUCTION}

DNA base composition has become a criterion for differentiation between staphylococci and micrococci (see for example Silvestri \& Hill, I965; Auletta \& Kennedy, I966). Therefore it is important to know the molar percentage of guanine plus cytosine in the total base content of the DNA (\% GC) of those staphylococci which are used as working types, as serotyping strains and for bio-assays.

We report here the DNA base composition of the strains of Staphylococcus aureus recommended for serological typing by Oeding (1952, 1957) and Haukenes (1967).

\section{METHODS}

All the I9 strains of Staphylococcus aureus investigated (Table I) were supplied by Dr P. Oeding, Department of Microbiology, University of Bergen, Norway, except CCM 885 which was obtained from the National Collection of Type Cultures.

Isolation of DNA. Lysis was carried out using lysostaphin by the method of Klesius \& Schuhardt (I968), but the subsequent process of recommended isolation was modified. Bacteria grown on nutrient agar at $37^{\circ}$ for $24 \mathrm{~h}$. were suspended in tris-saline-citrate (TSC) buffer; 0.05 M-tri-(hydroxymethyl)methylamine (tris), $0.145 \mathrm{M}-\mathrm{NaCl}, 0.015 \mathrm{M}$-trisodium citrate; adjusted to $\mathrm{pH} 7 \cdot 4$ with $\mathrm{HCl}$. After centrifugation, the bacteria were washed once with TSC and then resuspended in TSC, using $20 \mathrm{ml}$. for each $3 \mathrm{~g}$. wet weight. Lysis was induced by adding Ioo units lysostaphin (Mead Johnson, Research Centre, Evansville, Indiana, U.S.A.) and incubating at $37^{\circ}$ for 30 to $60 \mathrm{~min} .30 \mathrm{ml}$. of saline-EDTA solution $(0.15 \mathrm{M}-\mathrm{NaCl}, 0 . \mathrm{I} \mathrm{M}-\mathrm{EDTA}, \mathrm{pH} 8)$ and $5 \mathrm{ml}$. of a $20 \%(\mathrm{w} / \mathrm{v})$ solution of sodium lauryl sulphate were added. The lysate was left in a stoppered Erlenmeyer flask in a water bath at $60^{\circ}$ for I5 min., cooled, and an equal volume of chloroform-isoamyl alcohol $(24: \mathrm{I}, \mathrm{v} / \mathrm{v})$ was added. The mixture was shaken for $20 \mathrm{~min}$. and centrifuged to separate the upper aqueous layer from which the DNA was precipitated by addition of $\mathrm{I} \cdot 5 \mathrm{vol}$. of redistilled ethanol.

The precipitated DNA was dissolved in tenfold diluted standard saline-citrate (SSC) buffer: $0.15 \mathrm{M}-\mathrm{NaCl}, 0.015 \mathrm{M}-\mathrm{Na}_{3}$ citrate and incubated with $50 \mu \mathrm{g} . / \mathrm{ml}$. RNase (Calbiochem, Medford Street, Los Angeles, California, U.S.A.) at $37^{\circ}$ for 24 h. Deproteinization was 
completed by repeated shaking with chloroform-isoamyl alcohol. The DNA was precipitated again and, after redissolving, the turbid solution was cleared by centrifuging at $70,000 \mathrm{~g}$ for $45 \mathrm{~min}$.

Table I. List of strains used

Staphylococcus aureus CCM no.

I $486,2317,2323,2326,2327,2328$ 2330, 233 I, 2339, 2350, 2457, 885 $2458,2459,2460,246 \mathrm{I}$

$235 \mathrm{I}$

2352

2353

\section{Other numbers}

P. OEDING no. $263 ;$ I $503 ; 2253 ; 28 ; 365 ; 3647 ;$ F 2I ; I 7 A ; 3 I 89, 2095; IOI $5 ; 670 ; 6376 ; 5687$ and 830

ATCC 1 2600; NCTC 8532; CIP 65.8; PZH 727/55; strain s 33 R 4; COWAN III

ATCC 10832; NCTC 7121; PZH 590/54; strain WOOD 46

ATCC I 2598; NCTC 8530; CIP 65.6; PZH 725/55; COWAN I

ATCC I 2599; NCTC 853I; PZH 726/55; COWAN II

Abbreviations: ATCC $=$ American Type Culture Collection, Rockville, Maryland, U.S.A.; $\mathrm{CCM}=$ Czechoslovak Collection of Micro-organisms, Brno, Czechoslovakia; CIP = Collection of Institut Pasteur, Paris; NCTC $=$ National Collection of Type Cultures, London; $\mathrm{PZH}=$ Collection of Hygiene Institute, Warsaw.

Table 2. DNA base ratios (GC) of 19 serotypes of Staphylococcus aureus

\begin{tabular}{|c|c|c|c|c|}
\hline $\begin{array}{l}\text { Staphylococcus } \\
\text { aureus ССм no. }\end{array}$ & $T_{\mathrm{m}}{ }^{*}$ & $\% \mathrm{GC}+$ & $E_{260} / E_{280} \ddagger$ & $\% \mathrm{GC} \S$ \\
\hline 2457 & $64 \cdot 6$ & 30.2 & $1 \cdot 580$ & $33^{\circ} 0$ \\
\hline 2353 & $64 \cdot 7$ & 30.4 & $1 \cdot 560$ & $34 \cdot 5$ \\
\hline 2317 & $65 \circ 0$ & $3 I \cdot I$ & $1 \cdot 580$ & $33^{\circ} 0$ \\
\hline 2459 & 65.0 & $3 I \cdot I$ & $\mathrm{I} \cdot \mathbf{5 5 0}$ & $35^{\circ} 0$ \\
\hline $235 \mathrm{I}$ & 65.0 & $3 I \cdot I$ & $1 \cdot 600$ & $3 I \cdot 7$ \\
\hline 2350 & $65 \cdot 0$ & $3 I \cdot I$ & I 570 & 33.5 \\
\hline $233 \mathrm{I}$ & 65.0 & $3 I \cdot I$ & $1 \cdot 580$ & 33.0 \\
\hline 2339 & $65 \cdot 1$ & $3 I \cdot 4$ & I'570 & 33.5 \\
\hline 1486 & $65 \cdot 2$ & $3 I \cdot 6$ & $1 \cdot 565$ & $34^{\circ} 0$ \\
\hline 2330 & 65.4 & $3 I \cdot 8$ & I'570 & 33.5 \\
\hline 2323 & 65.4 & $3 I \cdot 8$ & $1 \cdot 600$ & $3 I \cdot 7$ \\
\hline $245^{8}$ & 65.4 & $31 \cdot 8$ & $\mathrm{I} \cdot 570$ & 33.5 \\
\hline 2460 & 65.4 & $31 \cdot 8$ & $\mathrm{I} \cdot 575$ & $33 \cdot 2$ \\
\hline 2326 & $65 \cdot 6$ & 32.4 & $1 \cdot 590$ & $32 \cdot 5$ \\
\hline 2327 & $65 \cdot 6$ & $32 \cdot 4$ & $\mathrm{I} \cdot 570$ & 33.5 \\
\hline $246 \mathrm{I}$ & $65 \cdot 7$ & $32 \cdot 7$ & $\mathrm{I} \cdot 580$ & 33.0 \\
\hline 2352 & 65.7 & $32 \cdot 7$ & $I \cdot 560$ & $34 \cdot 5$ \\
\hline 885 & 65.7 & $32 \cdot 7$ & $\mathrm{I} \cdot 550$ & 35.0 \\
\hline 2328 & 65.9 & $33 \cdot I$ & $\mathrm{I} \cdot 575$ & $33 \cdot 3$ \\
\hline
\end{tabular}

The clear solution containing DNA was carefully poured off and after adding $0 \cdot \mathrm{I}$ vol. of a solution containing $3 \mathrm{M}$-sodium acetate and $0.001 \mathrm{M}$-EDTA, $\mathrm{pH} 7$, the DNA was reprecipitated by gradual addition of ethanol ( $\mathrm{I}$ to $\mathrm{I} \cdot 5 \mathrm{vol}$.). The DNA fibres were dissolved in phosphate-EDTA (PE) buffer: 0.0I M-sodium phosphate, o.00I M-EDTA, pH 7. The protein content in the samples ranged from 0.5 to $3 \%$ (Folin reaction) and polysaccharides were estimated in the range of 2 to $7 \%$ (anthrone reaction; Roe \& Dailey, 1966).

Determination of the base composition of DNA. This was determined by two different methods: from the $T_{\mathrm{m}}$ values measured in PE buffer, and from the extinction ratio $E_{260} /$ $E_{280}$ measured spectrophotometrically in O.I M-acetic acid (Fredericq, Oth \& Fontaine, 
Table 3. The biochemical characteristics of 19 serotype strains of Staphylococcus aureus

\begin{tabular}{|c|c|c|c|c|c|c|c|}
\hline $\begin{array}{l}\text { Staphylococcus } \\
\text { aureus } \\
\text { ССм no. }\end{array}$ & Lactose & $\begin{array}{c}\text { Tween } \\
80\end{array}$ & Egg yolk & $\begin{array}{l}\text { Fibrino- } \\
\text { lysin }\end{array}$ & $\begin{array}{c}\text { Haemo- } \\
\text { lysin }\end{array}$ & Urease & Serological pattern* \\
\hline 2457 & $t^{3}$ & $+^{3}$ & $+^{3}$ & + & - & + & $c_{1}$ \\
\hline 2353 & +1 & +1 & $t^{2}$ & + & $\beta$ & - & $h_{2} / 263-2$ \\
\hline 2317 & $+^{1}$ & +1 & $t^{2}$ & - & - & - & $\mathrm{e} / \mathrm{m} / \mathrm{n}$ \\
\hline 2459 & $+{ }^{1}$ & $+{ }^{1}$ & - & - & $\alpha \beta$ & + & $c_{1}$ \\
\hline $235 \mathrm{I}$ & $+{ }^{1}$ & $t^{1}$ & $t^{2}$ & + & $\alpha \beta$ & - & $i_{1} i_{2}$ \\
\hline 2350 & +1 & $t^{1}$ & $t^{2}$ & - & - & - & $a_{4} / a_{5} / b_{1}$ \\
\hline 2331 & $+{ }^{1}$ & $+^{2}$ & $+^{2}$ & - & - & - & $a_{6} / h_{1} / h_{2} / 263-2$ \\
\hline 2339 & $t^{1}$ & $t^{2}$ & $t^{2}$ & - & - & - & NT \\
\hline 1486 & +1 & $+^{1}$ & $+^{1}$ & + & $\alpha$ & - & $a_{5} / k_{1} k_{2} / m / 263-I / 263-2$ \\
\hline 2330 & $+^{1}$ & $t^{1}$ & $t^{2}$ & - & - & - & $\mathrm{b}_{1} / \mathrm{c}_{1} / \mathrm{i}_{1} \mathrm{i}_{2} / \mathrm{m}$ \\
\hline 2323 & $++^{1}$ & $+^{2}$ & $+^{2}$ & - & - & - & $c_{1} / \mathrm{e} / \mathrm{m} / \mathrm{n}$ \\
\hline 2458 & $+^{3}$ & $t^{3}$ & $t^{3}$ & - & $\beta$ & + & $\mathrm{h}_{1} / \mathrm{h}_{2}$ \\
\hline 2460 & +1 & +1 & - & - & $\beta$ & + & $h_{2} / 263-2$ \\
\hline 2326 & - & $t^{2}$ & $t^{2}$ & - & - & - & $\mathrm{e} / \mathrm{n}$ \\
\hline 2327 & $+{ }^{1}$ & $+^{1}$ & $t^{2}$ & - & - & - & $b^{1} / k^{1}$ \\
\hline $246 \mathrm{I}$ & +1 & $t^{1}$ & - & + & $\alpha$ & + & \\
\hline 2352 & $+{ }^{1}$ & - & - & - & - & - & $\mathrm{h}_{2} / \mathrm{k}_{1} \mathrm{k}_{2} / \mathrm{m} / 26_{3}-\mathrm{I} / 263$ \\
\hline 885 & $t^{1}$ & $t^{1}$ & $t^{3}$ & - & $\alpha \beta$ & + & $a_{4} / a_{5} / b_{1} / c_{1} / n$ \\
\hline 2328 & $t^{1}$ & - & - & - & - & - & $a_{4} / a_{5} / b_{1} / c_{1} / n$ \\
\hline
\end{tabular}

All strains studied were catalase and benzidine test-positive, produced free and/or bound coagulase, produced acid anaerobically and aerobically from glucose and mannitol, produced acid aerobically from maltose and galactose, produced acetoin and phosphatase, were methyl-red positive, reduced nitrate and nitrite, produced $\mathrm{NH}_{3}$ from arginine, grew at $45^{\circ}$ and in presence of $15 \% \mathrm{NaCl}$.

None of the strains hydrolysed aesculin or starch, nor produced ornithine or lysine decarboxylases, nor phenylalanine deaminase, nor grew on Simmons citrate agar.

$+^{1},+^{2},+^{3}=$ Positive reaction after $\mathrm{I}, 2$ and 3 days respectively; $-=$ Negative reaction;

$\mathrm{NT}=$ Not typable, control st in. ${ }^{*} \mathrm{P}$. Oeding, personal communication.

196I). A detailed description of the methods used is given by Boháček, Kocur \& Martinec (1967).

Morphological properties and biochemical characteristics of the strains were studied according to the methods used by Mortensen \& Kocur (1967).

\section{RESULTS}

The GC contents of the DNA of the I9 strains of Staphylococcus aureus are given in Table 2 . The GC contents show a narrow range: $30 \cdot 2$ to $33.1 \%$ GC (average $31 \cdot 7$ ) from the $T_{\mathrm{m}}$ values measured in PE buffer, while a slightly wider range was found $3 \mathrm{I} \cdot 7$ to $35 \% \mathrm{GC}$ (average $33.4 \% \mathrm{GC}$ ) from the extinction ratios. The differences between the values obtained by these two methods ranged in most strains from $0 \cdot 1$ to $2 \% \mathrm{GC}$. Only three of the strains (CCM 2457, 2353 and 2459) showed differences of 3 to $4 \%$ GC. With the exception of strain CCM 2323, higher values were obtained by the method of Fredericq et al. (I96I). This fact has been already discussed in our previous work (Boháček, Kocur \& Martinec, 1970).

The biochemical characteristics and serological patterns of 19 strains of Staphylococcus aureus are given in Table 3. 


\section{DISCUSSION}

The isolation of DNA from strains of Staphylococcus aureus is difficult because the commonly used methods of enzymic and chemical lysis of bacterial cells are not very effective. The induction of osmotically fragile spheroplasts by adding penicillin to the growth medium is an exception, but this method has apparently been used for the purpose of isolating DNA by only Silvestri \& Hill (1965). The lytic enzyme lysostaphin, discovered by Schindler \& Schuhardt (1964), causes a rapid lysis of $S$. aureus cells and makes the isolation of DNA possible.

Our results are in agreement with the data obtained by Garrity, Detrick \& Kennedy (I969) and Klesius \& Schuhardt (1968), whose finding that lysostaphin was very effective in the isolation of DNA from staphylococci is confirmed. Two of our strains have been studied by other authors. For the strain CCM 885 (NCTC 8532 ), 3I $2 \%$ GC was reported by Silvestri \& Hill (1965), in comparison with our finding of $32 \cdot 7 \%$ GC (from $T_{\mathrm{m}}$ ). Garrity et al. (I969) reported $33.4 \%$ GC for strain CCM $235 \mathrm{I}$ compared with our estimate of $3 \mathrm{I} \cdot \mathrm{I} \% \mathrm{GC}$ (again from $T_{\mathrm{m}}$ ). Differences of $+\mathrm{I} \cdot 5$ and $-2 \cdot 3 \% \mathrm{GC}$, respectively, slightly exceed the range of the maximal experimental error reported by Marmur \& Doty (I962) which was I mole \% GC. Theoretical motivation of discrepancies in the results of GC measurements performed in buffers of different ionic strength has been recently reported by Owen, Hill \& Lapage (I969).

No correlation between GC content and a particular serological pattern or biochemical characteristics of Staphylococcus aureus strains was found.

We wish to thank Dr W. A. Zygmundt for providing lysostaphin, and Mr L. R. Hill and Dr. P. Oeding for helpful discussions.

\section{REFERENCES}

Auletta, A. E. \& Kennedy, E. R. (1966). Deoxyribonucleic acid base composition of some members of the Micrococcaceae. Journal of Bacteriology 92, 28-34.

Boh'́Č́E, J., KoCUR, M. \& MARTINeC, T. (1967). DNA base composition and taxonomy of some micrococci. Journal of General Microbiology 46, 369-379.

BohíČEK, J., KocUR, M. \& MARTINEC, T. (I970). DNA base composition of some Micrococcaceae. Microbios 6, 85-9I.

FredericQ, E., Oth, A. \& Fontaine, F. (I96I). The ultraviolet spectrum of deoxyribonucleic acids and their constituents. Journal of Molecular Biology 3, I I-I 7 .

Garrity, F. L., Detrick, B. \& Kennedy, E. R. (I969). Deoxyribonucleic acid base composition in the taxonomy of Staphylococcus. Journal of Bacteriology 97, 557-560.

Haukenes, G. (1967). Serological typing of Staphylococcus aureus. VII. Technical aspects. Acta pathologica et microbiologica scandinavica $\mathbf{7 0}, 560-600$.

Klesius, P. H. \& Schuhardt, V. T. (I968). Use of lysostaphin in the isolation of highly polymerized deoxyribonucleic acid and in the taxonomy of aerobic Micrococcaceae. Journal of Bacteriology 95 , 739-743.

Marmur, J. \& Doty, P. (1962). Determination of the base composition of deoxyribonucleic acid from its thermal denaturation temperature. Journal of Molecular Biology 5, 109-1 8.

Mortensen, N. \& Kocur, M. (I967). Correlation of DNA base composition and acid formation from glucose of staphylococci and micrococci. Acta pathologica et microbiologica scandinavica 69, 445-457.

OEdING, P. (1952). Serological typing of staphylococci. Acta pathologica et microbiologica scandinavica 93, Suppl. 356-363.

OEdING, P. (1957). Agglutinability of pyogenic staphylococci at various conditions. Acta pathologica et microbiologica scandinavica 4I, 310-324. 
Owen, R. J., HiLl, L. R. \& LAPAGE, S. P. (1969). Determination of DNA base composition from melting profiles in dilute buffers. Biopolymers 7, 503-516.

RoE, J. H. \& Dailey, R. E. (1966). Determination of glycogen with the anthrone reagent. Analytical Biochemistry 15, 245-250.

SCHINDLER, C. A. \& SCHUHARDT, V. T. (I964). Lysostaphin: a new bacteriolytic agent for the Staphylococcus. Proceedings of the National Academy of Sciences of the United States of America 5I, 4I4-42I.

Silvestri, L. C. \& Hill, L. R. (1965). Agreement between deoxyribonucleic acid base composition and taxometric classification of Gram-positive cocci. Journal of Bacteriology 9o, 136-140. 